\title{
Compression of Traditional and Computer Face Emotion Recognition Training in Children with Autism, Clinical Trial Study
}

\section{Saeid Bashirian}

Hamadan University of Medical Sciences School of Public Health

\section{Salman Khazaei}

Hamadan University of Medical Sciences

\section{Majid Barati}

Hamadan University of Medical Sciences School of Public Health

\section{Fatemeh Mirzaei}

Hamadan University of Medical Sciences School of Nursing and Midwifery

\section{Mohammad Rezaei}

Hamadan University of Medical Sciences

\section{Ensiyeh Jenabi}

Hamadan University of Medical Sciences

\section{Fatemeh Cheraghi}

Hamadan University of Medical Sciences School of Nursing and Midwifery

fateme mohammadi ( $\nabla$ mohammadifateme47@yahoo.com )

Hamadan University of Medical Sciences School of Nursing and Midwifery

\section{Research}

Keywords: emotional face, children, autism, parents

Posted Date: May 5th, 2021

DOI: https://doi.org/10.21203/rs.3.rs-458247/v1

License: (1) (1) This work is licensed under a Creative Commons Attribution 4.0 International License. Read Full License 


\section{Abstract \\ Background}

This study aimed to investigate the effect of traditional and computer emotional facial training on the recognition of facial emotional states in children with autism and mother -child relation and parental competence in mothers of autistic children.

\section{Methods}

The present clinical trial study was conducted in three childcare centers. In this study, children with high or moderate performance autism were selected by available sampling who were then assigned to the two groups using the random block sampling method. Thereafter, the children with autism in the both groups were trained during 10 sessions. In traditional group children training using 40 images related to four situations as happiness, sadness, anger, and fear. The children in the computer group trained with the Let's Face It software. These questionnaires were completed one day before and one day and one week after performing the intervention in both groups by assistant research. The obtained data were analyzed using SPSS software version 22.

\section{Result}

Findings showed that emotional state training has improved the identification of emotional states $(p=$ $0.01)$, mother -child relation $(p=0.001)$ and parental competence $(p=0.001)$ in the both groups. There was also a statistically significant difference between the scores of identifying face emotional states $(p=$ $0.01)$, mother - child relation $(p=0.001)$ and parental competence $(p=0.001)$ in the both groups. But training in traditional group was effectiveness than computer grope.

\section{Conclusions}

Teaching emotional face to children with autism improved the recognition of emotional states by these children, and subsequently improved the mother-child relationship and motherly sense of competence in the mothers of these children.

\section{Introduction}

Autism, also known as autistic spectrum disorder, has been ranked the third growth and development impairment among children after mental retardation and cerebral palsy[1]. Epidemiological studies shows that world has been experiencing more than $6 \%$ growth of prevalence[2], which has been raising about 0.5 to 1 percent in the population of each community in recent years[3]. Cause of various problems in term of cognition, movement and interaction, health-care providers will face many challenges in near 
future[4] also, the verbal, behavioral development and social interactions of these children will be effected negatively[5].

Admittedly, one of the most important behavioral-communicational problems in autistic children which will limit their interactions with family members and the community is emotional identification disability that subsequently would lead to inappropriate responses[6]. The impaired emotional perception consequently will result in attention deficit that makes problems with recognition of even familiar faces[7]. Therefore, in social situations they cannot establish a proper relationship between emotional symptoms and recognition of people's emotional states by their faces and speech tone or body language[8, 9]. Regarding to the interactions inefficiency especially with their mothers[10], mothers often give up their children's education[11]. Since, there is a direct and two-way relationship between mother and children, it seems to be efficient to encourage mothers toward their children's care and education which would improve parental competence which consequently result in improvement of mother-child interactions[12]. Parental competence is a multidimensional concept and defined as stability restoration in family in order to excellent children's care[13]. Studies show that gaining parental competence through the care and education of their autistic children causes parental roles fulfillment[14, 15]. Pediatric nurses as the main part of caregivers struggle to support the mothers and encourage them to engage in the medical care by developing family-centered care[15]. Whereas, family-centered care is the professional one and focus on the active participation of family members in daily care[16], it helps to improve family relationships and reduce the negative effects of children's illness[17]. so, the development of education children with autism based on family-centered care seems to be one of the most important responsibilities of nurses[18]. Accordingly, in recent years, several studies have examined the effect of emotional state training on improving the social interactions between autistic children and the world around them[19, 20].

As Conallen et al. (2016) stated in their study, traditional emotional facial training could improve emotional state recognition in different situations by autistic children which consequently develop their interactions with environment[21]. In addition, what make this method widespread in use is its cheapness, easy implementation, no eye fatigue for children and increase their interactions with the mother[22]. on the other hand, using computer games and watching animated cartoons are believed to improve the recognition of facial emotional states by children with autism and help them to overcome their fear to look at others faces to express their feelings better[23]. Hassanpour et al. (2019) have stated that facial emotional states training to high-functioning autistic children will promote the recognition of facial emotional states. Also, Ramdoss et al. stated that teaching facial emotional recognition to autistic children can reduce some of their behavioral problems[24,25]. Due to the raise of autism prevalence in Iran[26] and the lack of related studies on the evaluation of the effect of face emotional recognition training among the high and moderate functioning autistic children, the present study has been designed to investigate the effect of traditional and computer emotional facial training on the recognition of facial emotional states in children with autism and mother -child relation and parental competence in mothers of autistic children. 


\section{Method}

\section{Study design and participants}

The present study was a randomized controlled trial with two intervention groups conducted in a oneblind manner in three autism centers affiliated to the University of Medical Sciences in western Iran from January 2020 to July 2021. The study was approved by the Ethics Committee of the Hamadan University of Medical Sciences (IR.UMSHA.REC.1399.215). and recorded at the Clinical Trials Center (IRCT20190703044082N2).Having provided the sufficient information about procedure the consent was obtained from the participants. Inclusion criteria were as follows: age between 6 and 12 years old; high or moderate performance based on the psychiatrist's report and the Diagnostic and Statistical Manual of Mental Disorders ( DSM V) Guideline; obtaining a score of 22 from the instructor or a score of 19 from the mother based on the autism spectrum screening questionnaire; ability to understand and perform empirical instructions; ability to work with computer; no other physical, cognitive-developmental or mental disorder, having no visual impairment, no change in the type and dose of drugs used by the child in a month before the study, and the desire and consent of their parents to participate in this study. Meanwhile, the absence in three or more training sessions and change of the type and dose of drugs used by the child during the study resulted in their exclusion from this study.

These children were selected to participate in this study by available sampling. A total of 60 mothers of children with autism were screened for eligibility; 6 patients were ineligible and finally, 54 patients who gave written informed consent were enrolled and randomly assigned to one of two noted groups (computer training, 27 subjects; and traditional training, 27 subjects) using block randomization with a volume of 2 and an allocation ratio of 1:1 using a computer-generated randomization schedule, stratified by parity (two strata: first, and second). Notably, 2 mothers of the children in the traditional group refused to participate in the study due to the outbreak of COVID 2019, so they were excluded from the study (Fig. 1).

\section{Intervention}

The teaching emotional states pictures were held in a convenient room with educational pamphlets and the emotional face booklets for autistic children. The traditional group was trained throughout 10 sessions. Each session had 30 min duration per week in attendance of their mothers. The mothers learned how to teach the emotional states, and helped the researcher in process. Forty different pictures were considered as four situations of happiness, sadness, anger, and fear (each emotional state contains ten pictures). The appropriate emotional state is expected to be selected according to the target face under the supervision of mothers or researchers. All images were a boy in size of A5 and colorful. Individually each child was given an image, without any explanation, and then the child should select the proper image related to the target face. Each time he recognized an image correctly, he/she would encouraged by mother or researcher, so that the next picture would be given but, in case of wrong answer, the researcher or mother make the child to try once more or provide him an indirect reference to the correct one. If wrong answer was repeated again, he/she will directly refer to the correct one. This process 
will be continued by the time of correct answer recognition. In each session, four emotional states have been submitted through the four pictures to autistic children. Simultaneously beside the researcher, mothers learned how to teach their child, so once they expressed their tendency to teach, the researcher devolved the process o training to them, so that the proper education would be achievable. Meanwhile, the researcher supervised the mother's style of training and expressed some points whenever necessary. At the end of each training session, any obscurity would be resolved by researcher.

On the other hand, the computer training group was taught the Let's Face It software in 10 sessions of 30 minutes. Participant used a laptop individually, and each child played all the steps independently under supervision of the researcher and mother. To encourage the child to play as much as possible each game stage has points. At the end, each stage score will be determined and child's total score will be calculated. LFI software consists of 8 game links that include: lion, stork, zebra, monkey, rhino, crocodile, elephant and hippo. The hippo link was disabled in the application. The elephant link displays several faces on a sequence at the top, and one face is at the bottom of the page, the child must find one relevant face at the bottom. This link has been removed in previous studies due to difficulty, needs for high skills and speed, and also lack of sufficient validity for the autistic children. Therefore; it was removed in this study, too. Other links have two modes of recognition and expression. Different faces are displayed in recognition mode whereas the expression mode, displays the faces with different basic emotional states (happiness, sadness, fear, anger). That is to say, real human face is displayed in lion link and then automatically removed, other irrelevant faces are then displayed, here the child must find out the first face provided among all. In the monkey link, two same faces are displayed which one of them is without eyes and mouth. Here, the child should be able to pick up the most fitted mouth and eyes. Zebra link, the child has to click to see the picture and then find the same ones in pairs. In the rhino link, faces were hidden in a forest background, and the child had to find them. In the crocodile link, there is a face by default at the bottom of the page and other faces appear and disappear on the page, the child must select the same face.

In the stork link, a number of objects are displayed while a face looking at one of them, here the child must find that object. Finally, the research assistant, who was not aware of the allocation of individuals in the intervention groups, gathered the questionnaires for the children included in both groups one day before, one day after, and one week after performing the intervention.

\section{Measures}

\section{Demographic information questionnaire}

Included age, sex, economic status, number of children, number of sick children, number of children with autism and their severity of autism, parents' age, parents' educational level, parents' occupation, and living with parents.

\section{Modified Benton Face Recognition Scale}


In order to collect data, the modified Benton Face Recognition Scale has been used. The primary purpose of this scale is to assess the cognitive statuses of individuals in different situations. Moreover, it consists of 28 different emotional faces related to four emotional states (happiness, sadness, fear, and anger) and each emotional state has 7 images and the child must choose the appropriate option questioned according to the emotional states shown in the images. The time required to identify each image was 1 minute and the test score was estimated by counting the number of correct answers of the child's score[21]. The face, content, and reliability of this scale were examined in the study by Shiri et al. (2012). As a result, it had appropriate face and content validities and its reliability was estimated to be $98 \%[27]$.

\section{Mother-Child Relationship Questionnaire}

Mother-child relationship questionnaire designed by Ross in 1961, this is one of main questionnaires for assessing the mother-child relationship. It contains four subscales, namely acceptance, overprotection, leniency, and rejection which are rated based on a 5-point Likert scale. Each subscale consists of 12 items, yielding a total of 48 items. In this questionnaire, the items 1-39 have a positive score, while the items $40-48$ have a negative score. The numerical value for each answer is regarded as the raw score. To obtain the raw score of each subscale, the score of the items of each domain are added together. The higher score of the acceptance subscale and the lower scores of the other subscales indicate a better relationship. Face and content validity, as well as the reliability of this scale, were confirmed. The reliability of this scale with test-retest for subscales were as follows (acceptance: 0.77 , overprotection: 0.78, leniency: 0.71 , and rejection: 0.72 ), and for the whole scale was reported as $0.80 .[28]$

\section{Parental competence questionnaire for parents of children with autism}

One of the most accurate competency questionnaires for mothers of children with autism is the Parental Competence Questionnaire for Parents of Children with Autism, designed by Mohammadi et al. (2018), which has 25 items in 2 dimensions: adaptation to the present situation and excellence in care. The items are scored on a five-point Likert scale, ranging from very high to very low. In this questionnaire, the overall score is the sum of the scores of the items. All the items are positive statements. The time required to complete this questionnaire is approximately 10 to 20 minutes. The questionnaire possesses face and content validity and has passed convergent and discriminant exploratory and confirmatory factor analysis tests. Two indexes were used to determine the reliability of the questionnaire: internal homogeneity (Cronbach's alpha and split-half method) and consistency (test-retest). The results showed the Cronbach's alpha of the scale to be 0.979 and its test-retest correlation coefficient to be 0.90 , which confirm the high reliability of the instrument[10].

\section{Data analysis}

The data were analyzed using the SPSS statistical software, version 22. Data analysis was performed using descriptive and inferential statistical methods. Kolmogorov-Smirnov test showed that the data were normally distributed. Thus, the differences between the two study groups regarding demographic characteristics were evaluated by independent t-test, Fisher exact test, and Chi-square test. At baseline, 
the two groups were compared using independent t-test, and at any time period. Moreover, repeated measures analysis of variance was used to compare at the three time periods in each group. $\mathrm{P}<.05$ was considered to be statistically significant.

\section{Results}

The majority of participants were boys 33(61.1\%). Majority of them had moderate performance level in both groups. Mean age of the children in the computer group was $11.42 \pm 1.52$ years old, and mean age of the children in the traditional group was $11.61 \pm 1.06$ years old.

The majority of mothers in this study are self-employed as 24 subjects (44.4\%) with diploma as 15 subjects (27.7\%). Mean age of the mothers of autistic children in the computer group was $37.31 \pm 1.57$ years old, and mean age of the mothers of autistic children in the traditional group was $37.42 \pm 1.41$ years old. There was no significant statistical difference in the distribution of demographic characteristics among the both groups $(P>.05)$. (Table 1). 
Table 1

Demographic information of the participants in this study

\begin{tabular}{|c|c|c|c|c|}
\hline \multirow[t]{2}{*}{ Variable } & & Traditional & Computer & \multirow{2}{*}{$\begin{array}{l}\mathrm{P} . \\
\text { value }\end{array}$} \\
\hline & & $\mathbf{N}(\%)$ & $\mathbf{N}(\%)$ & \\
\hline \multirow{3}{*}{$\begin{array}{l}\text { Mother's age } \\
\text { (Year) }\end{array}$} & $24-33$ & $5(18.52)$ & $5(18.52)$ & \multirow[t]{3}{*}{$0.83^{*}$} \\
\hline & $34-44$ & $13(48.15)$ & $14(51.85)$ & \\
\hline & $45-55$ & $9(33.34)$ & $8(29 / 63)$ & \\
\hline \multirow[t]{5}{*}{ Mother's education } & illiterate & $2(7.41)$ & $3(11.11)$ & \multirow[t]{5}{*}{$1.71^{\star}$} \\
\hline & Primary & $5(18.52)$ & $5(18.52)$ & \\
\hline & Diploma & $7(25.93)$ & $8(29.63)$ & \\
\hline & Bachelor & $7(25.93)$ & $6(22.22)$ & \\
\hline & $\begin{array}{l}\text { Master's degree and } \\
\text { higher }\end{array}$ & $6(22.22)$ & $5(18.52)$ & \\
\hline \multirow[t]{5}{*}{ Father's education } & illiterate & $3(11.11)$ & $2(7.41)$ & \multirow[t]{5}{*}{$0.77^{*}$} \\
\hline & Primary & $4(14.81)$ & $3(11.11)$ & \\
\hline & Diploma & $10(37.04)$ & $11(40.74)$ & \\
\hline & Bachelor & $6(22.22)$ & $7(25.93)$ & \\
\hline & $\begin{array}{l}\text { Master's degree and } \\
\text { higher }\end{array}$ & $4(14.81)$ & $4(14.81)$ & \\
\hline \multirow[t]{3}{*}{ Mother's Jab } & Self-employed & $11(40.74)$ & $13(48.15)$ & \multirow[t]{3}{*}{$0.73^{*}$} \\
\hline & Employee & $9(33.34)$ & $8(29.63)$ & \\
\hline & housewife & $7(25.93)$ & $6(22.22)$ & \\
\hline \multirow[t]{3}{*}{ Father's Jab } & Self-employed & $13(48 / 15)$ & $15(55.56)$ & \multirow[t]{3}{*}{$0.77 *$} \\
\hline & Employee & $7(25.93)$ & $7(25.93)$ & \\
\hline & Livestock and Farmer & $7(25.93)$ & $5(18.52)$ & \\
\hline \multirow[t]{3}{*}{ Number of children } & 1 & $7(25.92)$ & $8(29.63)$ & \multirow[t]{3}{*}{$0.89 *$} \\
\hline & $2-3$ & $14(51.86)$ & $13(48.15)$ & \\
\hline & 4 and more & $6(22.22)$ & $6(22.22)$ & \\
\hline \multirow{2}{*}{$\begin{array}{l}\text { Number of children with } \\
\text { autism }\end{array}$} & 1 & $25(92.59)$ & $26(96.30)$ & \multirow[t]{2}{*}{$0.92^{*}$} \\
\hline & $2-3$ & $2(7.41)$ & $1(3.70)$ & \\
\hline
\end{tabular}




\begin{tabular}{|c|c|c|c|c|}
\hline \multicolumn{2}{|l|}{ Variable } & $\begin{array}{l}\text { Traditional } \\
\text { group } \\
\mathbf{N}(\%)\end{array}$ & $\begin{array}{l}\text { Computer } \\
\text { group } \\
\mathrm{N}(\%)\end{array}$ & $\begin{array}{l}\mathrm{P} \text {. } \\
\text { value }\end{array}$ \\
\hline \multirow[t]{3}{*}{ Child guardian } & Mother & $2(7.41)$ & $2(7.41)$ & \multirow[t]{3}{*}{$0.75^{\star \star}$} \\
\hline & Father & $5(18.52)$ & $4(14.81)$ & \\
\hline & $\begin{array}{l}\text { Mother-father (both } \\
\text { parents) }\end{array}$ & $20(74.07)$ & $21(77.78)$ & \\
\hline \multirow[t]{3}{*}{ The economic situation } & mild & 10(37.05) & $8(29.63)$ & \multirow[t]{3}{*}{$0.71^{*}$} \\
\hline & moderate & $13(48 / 15)$ & $15(55.56)$ & \\
\hline & severe & $4(14.81)$ & $4(14.81)$ & \\
\hline \multirow[t]{2}{*}{ Sex of children } & boy & $16(59.26)$ & $17(62.96)$ & \multirow[t]{2}{*}{$0.91 *$} \\
\hline & girl & $11(40.74)$ & $10(37.04)$ & \\
\hline \multirow[t]{3}{*}{ Children's age } & $6-8$ & $7(25.92)$ & $6(22.22)$ & \multirow[t]{3}{*}{$0.85^{\star}$} \\
\hline & $8-10$ & $11(40.74)$ & $13(48.15)$ & \\
\hline & $10-12$ & $9(33.34)$ & $8(29.63)$ & \\
\hline \multirow[t]{2}{*}{ Level of autism in children } & High performance & $9(33.34)$ & 10(37.04) & \multirow[t]{2}{*}{$0.90 *$} \\
\hline & Medium performance & 18(66.66) & $17(62.96)$ & \\
\hline
\end{tabular}

Chi- square*

** Fisher exact test

\section{Face emotion recognition in children with autism}

At first, both groups acted poorly in emotional facial recognition in the four states of happy, sadness, and fear, and especially anger, however after training the process great improvement has been occurred in both groups (Table 2). There was no significant statistical difference in emotional facial scores at the beginning among them $(p=0.93)$ but having performed emotional facial training, significant difference was observed between the computer and traditional groups in one day and one week after the intervention. Traditional group showed better performance than the computer group $(p=0.01)$. Furthermore, intra group comparison of emotional facial scores during the study was statistically significant in each group $(p=0.01)$, which showed the effectiveness of emotional facial education even after a week. (Table 3) 
Table 2

Mean of face emotion recognition scores in any emotional state of the face between both groups

\begin{tabular}{|c|c|c|c|c|c|}
\hline \multicolumn{2}{|l|}{ Study days } & \multirow{2}{*}{$\begin{array}{l}\text { Before } \\
\text { intervention } \\
\text { (SD) }\end{array}$} & \multirow{2}{*}{$\begin{array}{l}\text { The first day after the } \\
\text { intervention } \\
\text { (SD) }\end{array}$} & \multirow{2}{*}{$\begin{array}{l}\text { Seventh day after } \\
\text { intervention } \\
\text { (SD) }\end{array}$} & \multirow{2}{*}{$\begin{array}{l}\text { P. } \\
\text { value }\end{array}$} \\
\hline Study group & & & & & \\
\hline \multirow{4}{*}{$\begin{array}{l}\text { Traditional } \\
\text { group }\end{array}$} & Happiness & $4.24(2.46)$ & $26.22(8.15)$ & $26.76(6.03)$ & $0.021 *$ \\
\hline & Sadness & $3.14(2.16)$ & $25.72(8.42)$ & $25.66(6.74)$ & $0.031 *$ \\
\hline & Anger & $1.84(2.96)$ & $24.31(8.63)$ & $25.12(5.33)$ & $0.023^{*}$ \\
\hline & Fear & $2.27(2.36)$ & $24.31(8.05)$ & $25.44(5.89)$ & $0.022^{*}$ \\
\hline \multirow{4}{*}{$\begin{array}{l}\text { Computer } \\
\text { group }\end{array}$} & Happiness & $4.24(2.46)$ & $6.74(5.36)$ & $4.74(4.64)$ & $0.035^{\star}$ \\
\hline & Sadness & $3.85(2.11)$ & $4.04(5.67)$ & $4.32(5.01)$ & $0.039 *$ \\
\hline & Anger & $1.92(2.47)$ & $2.04(4.28)$ & $2.11(4.07)$ & $0.043^{\star}$ \\
\hline & Fear & $2.27(2.15)$ & $2.74(5.61)$ & $2.78(5.11)$ & $0.040 *$ \\
\hline
\end{tabular}

* Repeated Measure test

Table 3

Comparison of face emotion recognition scores between both groups

\begin{tabular}{|lllll|}
\hline Study days & $\begin{array}{l}\text { Before } \\
\text { intervention } \\
\text { Mean (SD) }\end{array}$ & $\begin{array}{l}\text { The first day after the } \\
\text { intervention } \\
\text { Mean (SD) }\end{array}$ & $\begin{array}{l}\text { One week after } \\
\text { intervention } \\
\text { Mean (SD) }\end{array}$ & $\begin{array}{l}\text { P. } \\
\text { value }\end{array}$ \\
\hline $\begin{array}{l}\text { Study groups } \\
\text { group }\end{array}$ & $4.74 \pm 3.46$ & $10.65 \pm 3.22$ & $10.43 \pm 5.42$ & $0.01^{* *}$ \\
\hline $\begin{array}{l}\text { Computer } \\
\text { group }\end{array}$ & $4.84 \pm 3.96$ & $8.87 \pm 5.22$ & $8.74 \pm 5.11$ & $0.01^{* *}$ \\
\hline P.Value & $0.93^{*}$ & $<0.01^{*}$ & $<0.01^{*}$ & \\
\hline
\end{tabular}

* In depended t-test

** Repeated Measure test

\section{Mother-child relationship in mothers of children with autism}

Before the intervention, both groups were statistically same in the mother-child relationship score ( $P=$ 0.87). Nonetheless, the repeated measures analysis of variance demonstrated a statistically significant difference in the mother-child relationship score in the both groups one day and one week after the intervention $(P=<0.001)$. Moreover, the independent t-test revealed a statistically significant difference between both groups in terms of mother-child relationship score $(P<0.001$; Table 4$)$. Furthermore, a great 
difference was observed between the scores of the mother-child relationship in all domains in the each group at three time periods (Table 4).

Table 4

Comparison of mother-child relationship scores between both groups

\begin{tabular}{|c|c|c|c|c|c|}
\hline \multicolumn{2}{|l|}{ Study days } & \multirow{2}{*}{$\begin{array}{l}\text { Before } \\
\text { intervention } \\
\text { Mean (SD) }\end{array}$} & \multirow{2}{*}{$\begin{array}{l}\text { The first day after } \\
\text { the intervention } \\
\text { Mean (SD) }\end{array}$} & \multirow{2}{*}{$\begin{array}{l}\text { One week after } \\
\text { intervention } \\
\text { Mean (SD) }\end{array}$} & \multirow[t]{2}{*}{$P$ value } \\
\hline Study groups & & & & & \\
\hline \multirow[t]{3}{*}{ Acceptance } & $\begin{array}{l}\text { Traditional } \\
\text { group }\end{array}$ & (98.3) 59.30 & (36.3)42.21 & (55.3) 42.91 & $0.001^{\star \star *}$ \\
\hline & $\begin{array}{l}\text { Computer } \\
\text { group }\end{array}$ & (243.) 30.43 & (16.8) 39.07 & (933.)39.29 & $0.001^{\star \star *}$ \\
\hline & $P$ value & $\star 0.95$ & $0.01^{*}$ & $0.01^{*}$ & \\
\hline \multirow[t]{3}{*}{ Overprotection } & $\begin{array}{l}\text { Traditional } \\
\text { group }\end{array}$ & (78.5) 70.30 & (26.7) 81.41 & (85.15(5.42 & $0.001^{\star \star *}$ \\
\hline & $\begin{array}{l}\text { Computer } \\
\text { group }\end{array}$ & (644.) 5629. & (317.) 2438. & $38.17(5.64)$ & $0.001^{\star \star *}$ \\
\hline & $P$ value & $0.87^{\star}$ & $0.01^{*}$ & $0.01^{*}$ & \\
\hline \multirow[t]{3}{*}{ Overindulgence } & $\begin{array}{l}\text { Traditional } \\
\text { group }\end{array}$ & (68.4).4331 & (936.)22.42 & (076.).1642 & $0.001^{\star \star}$ \\
\hline & $\begin{array}{l}\text { Computer } \\
\text { group }\end{array}$ & (764.) 44.30 & (79.6)6438. & (99.6)3438. & $0.001^{\star \star}$ \\
\hline & $P$ value & $0.79 *$ & $0.01 *$ & $0.01 *$ & \\
\hline \multirow[t]{3}{*}{ Rejection } & $\begin{array}{l}\text { Traditional } \\
\text { group }\end{array}$ & (25.5) 11.30 & (65.6) 4443. & (10.6) 3443. & $0.001^{\star \star *}$ \\
\hline & $\begin{array}{l}\text { Computer } \\
\text { group }\end{array}$ & (71.4) 96.29 & (067.) 0440. & (576.) 8841. & $0.001^{\star *}$ \\
\hline & $P$ value & $0.92^{\star}$ & $0.01^{*}$ & $0.01^{*}$ & \\
\hline \multirow[t]{3}{*}{ Total score } & $\begin{array}{l}\text { Traditional } \\
\text { group }\end{array}$ & (74122.83(3) & (895.)169.68 & $5.62)) 170.65$ & $0.001^{\star *}$ \\
\hline & $\begin{array}{l}\text { Computer } \\
\text { group }\end{array}$ & $(52.4) 120.42$ & (86.1) 155.81 & (5.75)157.77 & $0.001^{\star \star *}$ \\
\hline & $P$ value & $0.87^{\star}$ & $0.001 *$ & $0.001^{*}$ & \\
\hline
\end{tabular}

* In depended t-test

** Repeated Measure test

Parental competence in mothers of children with autism 
Parental competence in autistic children's parent was not statistically significant between the computer and traditional groups before the intervention $(p=0.91)$; but, the repeated measures analysis of variance has showed a statistically significant difference in parental competence score in both groups after the intervention $(p=0.001)$. Also, independent t-test showed the statistically significant difference between the scores of parental competence in both groups $(p=0.001)$ (Table 5). Furthermore, a statistically significant difference was observed between the scores of the parental competence in all domains in the each group at any time period (Table 5)

Table 5

Comparison of parental competence scores between both groups

\begin{tabular}{|c|c|c|c|c|c|}
\hline \multicolumn{2}{|l|}{ Study days } & \multirow{2}{*}{$\begin{array}{l}\begin{array}{l}\text { Before } \\
\text { intervention }\end{array} \\
\text { Mean (SD) }\end{array}$} & \multirow{2}{*}{$\begin{array}{l}\text { The first day after } \\
\text { the intervention } \\
\text { Mean (SD) }\end{array}$} & \multirow{2}{*}{$\begin{array}{l}\text { One week after } \\
\text { intervention } \\
\text { Mean (SD) }\end{array}$} & \multirow{2}{*}{$\begin{array}{l}P \\
\text { value }\end{array}$} \\
\hline Study groups & & & & & \\
\hline \multirow[t]{3}{*}{$\begin{array}{l}\text { adaptation with the } \\
\text { present situation }\end{array}$} & $\begin{array}{l}\text { Traditional } \\
\text { group }\end{array}$ & $\begin{array}{l}(231 .) \\
.0723\end{array}$ & (1.31) 22.34 & (1.42) 19.34 & $0.001 *$ \\
\hline & $\begin{array}{l}\text { Computer } \\
\text { group }\end{array}$ & $(04.1) 52.23$ & (1.75)30.44 & (1.33)30.04 & \multirow[t]{2}{*}{$0.001 *$} \\
\hline & $P$ value & $0.90 *$ & $0.001^{\star}$ & $0.001 *$ & \\
\hline \multirow[t]{3}{*}{ Excellence in care } & $\begin{array}{l}\text { Traditional } \\
\text { group }\end{array}$ & $\begin{array}{l}(1.23) \\
28.30\end{array}$ & (1.65) 8941. & (1.39) 5941. & $0.001 *$ \\
\hline & $\begin{array}{l}\text { Computer } \\
\text { group }\end{array}$ & $\begin{array}{l}(98.1) \\
6427 .\end{array}$ & (1.42)08.30 & (1.81) 7829. & \multirow[t]{2}{*}{0.001 * } \\
\hline & $P$ value & $0.89 *$ & $0.001 *$ & $0.001 *$ & \\
\hline \multirow[t]{3}{*}{ Total score } & $\begin{array}{l}\text { Traditional } \\
\text { group }\end{array}$ & 1.32))37.51 & (1.84)1176. & (741.) 7875 . & $0.001 *$ \\
\hline & $\begin{array}{l}\text { Computer } \\
\text { group }\end{array}$ & $\begin{array}{l}(471 .) \\
51.16\end{array}$ & (1.91) 60.52 & (271.) 59.91 & \multirow[t]{2}{*}{0.001 * } \\
\hline & $P$ value & $0.91^{*}$ & $0.001 *$ & $0.001 *$ & \\
\hline
\end{tabular}

* In depended t-test

** Repeated Measure test

\section{Discussion}

The recent findings showed that both traditional and computerized methods promote the recognition of emotional facial state in autistic children and consequently improve mother-child interaction and parental competence in autistic children's mother. Although both educational methods have been effective, the traditional method seems to be more effective than the other. Whereas there have not been any other 
article which compare three main variables; recognition of facial expressions by autistic children, and the effect of this educational method on the child's mother-mother relationship and maternal competence at same time, this study try to assess the likely relation among them. As it mentioned, teaching of emotional facial recognition based on a family-centered approach, with an active attendance of mothers promoted the results by autistic children in both groups, and consequently provide more appropriate behavioral responses to interaction with others. Hassanpour et al. (2019) stated that the autistic children performed poorly in identifying facial expressions and scored low, but having been trained, their response got better. There was a statistically significant difference between emotional facial scores before and after the intervention[24]. Whereas the emotional face training impact in cited study was assessed among 5 highfunctioning autistic children as a single group without the follow-up consideration, the present study examined a larger number of autistic children with high and moderate functional. That is to say, the emotional facial education can be effective in autistic children either high or moderate performance along the time. Admittedly, the results are same as Conallen et al have studied (2016) on 10 autistic children with high-functioning as single group. Since, children's ability of emotional states identification basically was weak, the 10 sessions training of facial expressions improved their ability[21]. Silver and Oaks (2001) stated that although the distinction of tired and thoughtful faces in Asperger's syndrome children was hard, emotional - facial education had remarkable impact on these children[29]. In addition, Shiri et al. (2013) stated that computer training could also improve the diagnosis of the emotional states of joy, sadness, anger, and fear in high-functioning autistic children[27]. Najafi et al. (2016) have also reported the positive impact of emotional facial training with the computer program on the recognition of emotional states in intervention group compared to the control group[30]. In spite of present study, eye contact and face-to-face communication was limited in mentioned study. Based on recent findings, before the intervention, there was no statistically significant difference in the mean scores of mother-child relationship between the traditional and computer groups. Cause of family-centered approach and active participation of mothers in process, mother-child interactions in both groups had significant promotion. These findings indicate the effectiveness of current training to high and moderate performance autistic children on mother-child interactions. In this regard, Hassanpour et al. (2019) also stated that mothers' relationship with autistic children was weak and inefficient at the beginning of the study, but after intervention the average scores of mother-child interaction in the whole questionnaires has increased dramatically[24]. Ghasempour et al. (2014) also stated that autistic children are reluctant to interact with others, even their mothers so, emotional face education has led to social interactions development[31]. On the other hand, Farran et al. proved that due to the slow process in emotional states of fear, anger, and sadness, the effective and constructive interaction would be damaged. Facial emotion recognition training seems to improve their social interactions[32]. In other words, there was no significant difference in result of parental competence between the traditional and computer groups before the intervention ,but emotional facial recognition teaching with family-centered approach and mother's active participation promoted parental competence in both groups(traditional, computerized) of autistic children with high or moderate function. In connection with the recent study, Shahidi et al. (2015) stated that parents especially mothers as primary caregivers has reported that the autistic children have a little tendency to communicate with people around like family members and even mothers. This problem results in various

Page $13 / 18$ 
difficulties in their education and consequently overwhelms them with feel of inefficiency, low self-esteem and parental incompetence[33]. Bagherian et al. (2016) showed that the Little Bird educational program for high-functioning autistic children has improved the child's mood, adaptability, and subsequently parental competence and mother-child attachment[34]. Therefore, it seems that the participation of parents especially mothers in educational programs can be effective to increase their self-efficacy and competence. Solish et al. (2008) also stated that parents' attendance in care programs has close relation with their behavioral intervention attitude, their self-efficacy and parental competence, so parental selfefficacy and competence are the most important predictors of parental involvement in Care programs of these children. Regardless to the type of behavioral education in this study, participation of parents leaded to promote their parental sense of competence, which is same with the findings of this study[35].

\section{Limitations and suggestions:}

One of the most important limitations of the present study was the pandemic of COVID disease 2019. Another limitation was the small sample size of the study. Accordingly, it is suggested to perform similar studies in next years in different communities and with larger sample sizes, in order to estimate the effect of emotional faces on improving interactions in autistic children more accurately.

\section{Conclusion}

Finally, it can be said that facial emotional teaching will lead to better recognition of facial emotional states by autistic children and consequently promotes mother-child interactions and parental competence. So, it seems that health officials and policy makers can benefit from the findings of this study by using emotional facial education to improve the quality of communication among autistic children with parents, and even the parental competence in parents of autistic children.

\section{Abbreviations}

There is any abbreviation in this manuscript.

\section{Declarations}

\section{Ethics approval and consent to participate}

The study design was approved by the Ethics Committee of the Hamadan University of Medical Sciences (IR.UMSHA.REC.1399.215), and recorded at the Clinical Trials Center. Also, at the beginning of study, the researcher introduced herself and explained the aims of this study, and the written informed consent was obtained from all the participants after providing them with sufficient information on the study. The participants were assured that all information would remain confidential. The researcher created the opportunity for participants to inform the researcher about their withdrawal from the study at any stage of the study and assured them that their lack of participation or withdrawal would not have any consequences for them. 


\section{Consent for Publication}

Not applicable

\section{Availability of data and materials}

The datasets used and/or analyzed during the current study are available from the corresponding author on reasonable request

\section{Competing interests}

The authors declare that they have no competing interests.

\section{Funding}

This research did not receive any specific grant from funding agencies in the public, commercial, or not for profit sectors.

\section{Authors' contributions}

$\mathrm{FM}, \mathrm{SB}, \mathrm{SKH}, \mathrm{FM}, \mathrm{FCH}, \mathrm{MB}, \mathrm{EJ}$ and MR were involved in the conception of the study and designed the study. They are responsible for data collection. Then S KH analyzed data. FM, SB and SKH drafted the primary manuscript

\section{Acknowledgement}

This article is the result of a research project issued by Hamadan University of Medical Sciences. Hereby, we researchers send our sincerest thanks to respected authorities of Hamadan Midwifery and Nursing University, autism centers, in Hamadan, mothers, and other people who contributed us in carrying out this study.

\section{References}

1. Gurney JG, Fritz MS, Ness KK, Sievers P, Newschaffer CJ, Shapiro EG. Analysis of prevalence trends of autism spectrum disorder in Minnesota. ARCH PEDIATR ADOLESC MED. 2003;157(7):622-7.

2. Smith LE, Hong J, Seltzer MM, Greenberg JS, Almeida DM, Bishop SL. Daily experiences among mothers of adolescents and adults with autism spectrum disorder. J Autism Dev Disord. 2010;40(2):167-78.

3. McGuire A. War on autism: On the cultural logic of normative violence. University of Michigan Press; 2016.

4. Ghorbani M. List of Autism centers regarded to welfare Organization. MNA. 2017.

5. Suzuki K, Kobayashi T, Moriyama K, Kaga M, Hiratani M, Watanabe K, et al. Development and evaluation of a parenting resilience elements questionnaire (PREQ) measuring resiliency in rearing 
children with developmental disorders. PloS one. 2015;10(12):e0143946.

6. Nasseh H. Company with autism diagnosis and treatment. Tehran: Danjeh press; 2010.

7. Somerville M, Williams C. Sustainability education in early childhood: An updated review of research in the field. ECEC. 2015;16(2):102-17.

8. Lacava PG, Golan O, Baron-Cohen S, Smith Myles B. Using assistive technology to teach emotion recognition to students with Asperger syndrome: A pilot study. Remedial Special Education. 2007;28(3):174-81.

9. Golan O, Baron-Cohen S, Ashwin E, Day K, McClintock S, Leggett V, editors. Facilitating emotional understanding and face-processing in young children with autism spectrum conditions using animations of vehicles with faces. British Psychological Scoiety Annual Conference; 2008.

10. Mohammadi F, Rakhshan M, Molazem Z, Zareh N, Gillespie M. Development of parental competence scale in parents of children with autism. "J Pediatr Nurs. 2020;50:e77-84.

11. Mouton PY, Tuma JM. Stress, locus of control, and role satisfaction in clinic and control mothers. J Clin Child Psychol. 1988;17(3):217-24.

12. Reder P, Duncan S. Lost innocents: A follow-up study of fatal child abuse. Routledge; 2013.

13. Soanes C, Hawker S. Compact Oxford english dictionary. Oxford University Press Oxford; 2003.

14. Zuck RB. Precious in His sight: Childhood and children in the Bible. Wipf and Stock Publishers; 2012.

15. Tarkka MT. Predictors of maternal competence by first-time mothers when the child is 8 months old. J Adv Nurs. 2003;41(3):233-40.

16. Schulz KP, Fan J, Bédard A-CV, Clerkin SM, Ivanov I, Tang CY, et al. Common and unique therapeutic mechanisms of stimulant and nonstimulant treatments for attention-deficit/hyperactivity disorder. JAMA Psychiatry. 2012;69(9):952-61.

17. Zeinali J, Mirhaghjou SN, Mirzaei M, Alhani F, Kazem Nezhad Leili E, Dehghani M. The effect of family centered care on meeting parental information needs of hospitalized children. J Holist Nurs. 2012;22(1):30-7.

18. Sohrabi Z, Narimani M. The roles of HEXACO personality dimensions and affects control in prediction of marital satisfaction. J Fundam Mental Health. 2018;20(3):219-27.

19. Baron-Cohen S. The hyper-systemizing, assortative mating theory of autism. Prog Neuropsychopharmacol Biol Psychiatry. 2006;30(5):865-72.

20. Tanaka JW, Wolf JM, Klaiman C, Koenig K, Cockburn J, Herlihy L, et al. Using computerized games to teach face recognition skills to children with autism spectrum disorder: the Let's Face It! program. J Child Psychol Psychiatry. 2010;51(8):944-52.

21. Conallen K, Reed P. A teaching procedure to help children with autistic spectrum disorder to label emotions. Res Autism Spectr Disord. 2016;23:63-72.

22. Emami Sigaroudi A, Kazemnezhad-Leyli E, Poursheikhian M. Compare the effect of two electronic and traditional education methods on first principles of instruction in nursing students of Guilan University of Medical Sciences in 2016. Med Educ. 2018;10(1):48-55. 
23. Dautenhahn K, Billard A, editors. Games children with autism can play with Robota. Universal access and assistive technology: proceedings of the Cambridge workshop on UA and AT; 2013.

24. HasanPour M, Moradi V, Yaghoubnezhad S, Haghani S. To investigate the effect of face emotion recognition training to children with high-functioning Autism on their mother-child relationship. RJMS. 2019;26(6):54-63.

25. Ramdoss S, Machalicek W, Rispoli M, Mulloy A, Lang R, O’Reilly M. Computer-based interventions to improve social and emotional skills in individuals with autism spectrum disorders: A systematic review. Developmental neurorehabilitation. 2012;15(2):119-35.

26. Boutet I, Collin C, Faubert J. Configural face encoding and spatial frequency information. Percept Psychophys. 2003;65(7):1078-93.

27. Shiri Ei, Nejati V, PoueEtemad H. Investigation of the effectiveness of cognitive rehabilitation on improving the distinguishing of emotional states in children with high functioning autism disorder. Except Child. 2013;13(3):5-14.

28. Nazemian A. Effectiveness of triple positive parenting program based on Iranian culture on motherchild relationship and children's academic achievement. mjms. 2016;59(2):124-31.

29. Silver M, Oakes P. Evaluation of a new computer intervention to teach people with autism or Asperger syndrome to recognize and predict emotions in others. Autism. 2001;5(3):299-316.

30. NAJAFI M, EFFECT OF “LET'S MAHAKIB. FACE IT” COMPUTER GAME ON IMPROVING FACE RECOGNITION SKILLS IN PATIENTS WITH AUTISM SPECTRUM DISORDERS. 2016.

31. Ghasempour S, Borjali A, Mohammadi M. The Effectiveness of Recognition of Excitement Training on Social Autistic Children's Skills Performance. Psychol Except Person. 2014;15:73-90.

32. Farran EK, Branson A, King BJ. Visual search for basic emotional expressions in autism; impaired processing of anger, fear and sadness, but a typical happy face advantage. Res Autism Spectr Disord. 2011;5(1):455-62.

33. Heydari A, Shahidi LH, Mohammadpour A. Spiritual journey in mothers' lived experiences of caring for children with autism spectrum disorders. Glob J Health Sci. 2015;7(6):79.

34. BAGHERIAN KS, POURETEMAD HR, FATHABADI J, FAYEZI N. MOHAMMADI M. Developing “Family Integrated Treatment" for Autistic Disorders and Comparing its Efficacy on Decreasing Parenting Stress of Parents of Autistic Children with “Little Bird” Method. 2016.

35. Solish A, Perry A. Parents' involvement in their children's behavioral intervention programs: Parent and therapist perspectives. Research in Autism Spectrum Disorders. 2008;2(4):728-38.

\section{Figures}




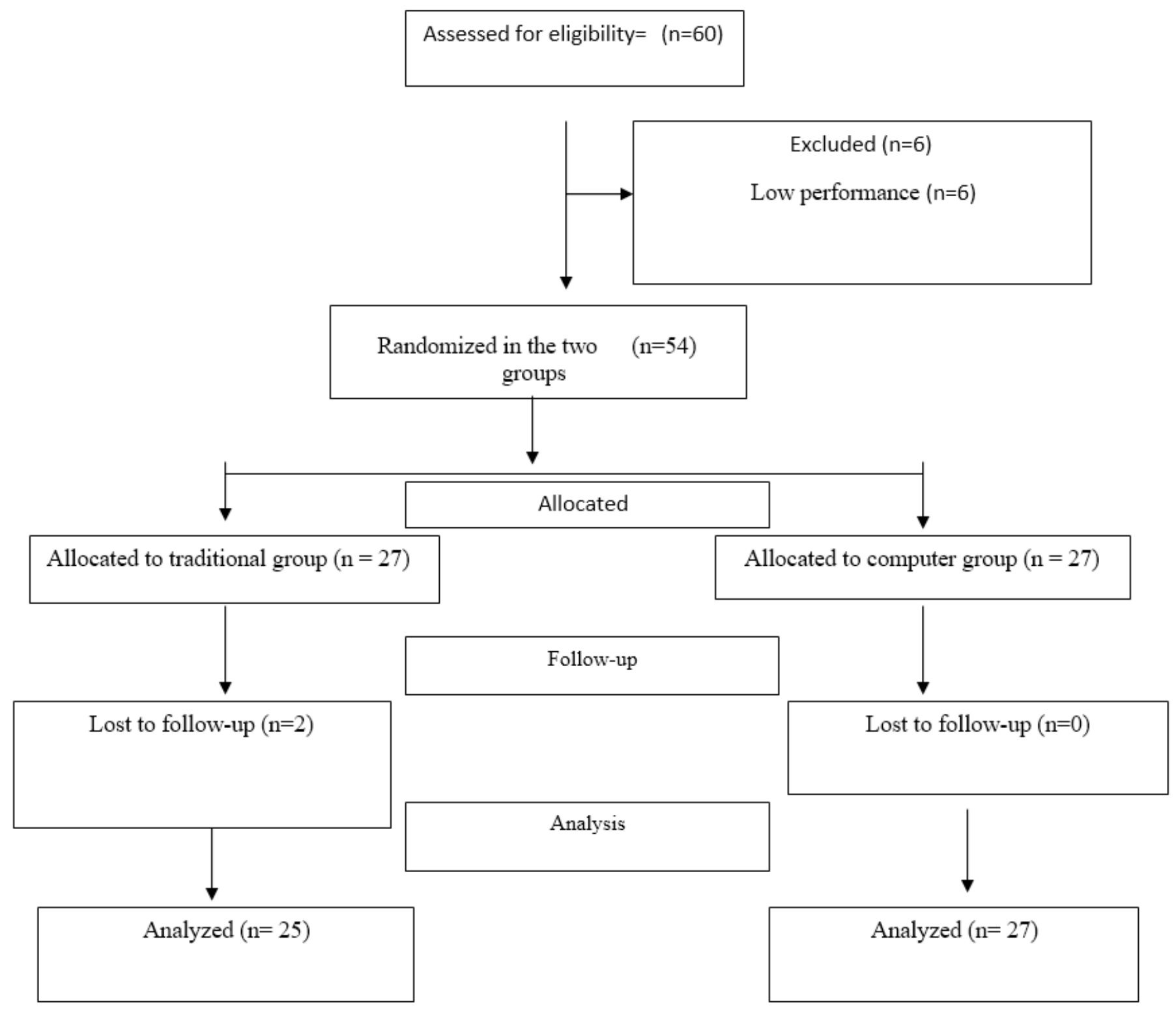

\section{Figure 1}

The Study Design 